\title{
Human T helper cells in immunity and autoimmunity: Th17 and beyond
}

F Sallusto

From 5th European Workshop on Immune-Mediated Inflammatory Diseases

Sitges-Barcelona, Spain. 1-3 December 2010

Abstract not submitted for publication

Published: 25 November 2010

doi:10.1186/1479-5876-8-S1-19

Cite this article as: Sallusto: Human T helper cells in immunity and

autoimmunity: Th17 and beyond. Journal of Translational Medicine 2010

8(Suppl 1):19.

Submit your next manuscript to BioMed Central and take full advantage of:

- Convenient online submission

- Thorough peer review

- No space constraints or color figure charges

- Immediate publication on acceptance

- Inclusion in PubMed, CAS, Scopus and Google Scholar

- Research which is freely available for redistribution 